\title{
Paradoxical Identity:
}

The changing nature of architectural work and its relation to architects' identity

\author{
Sumati Ahuja \\ University of Technology Sydney \\ Sumati.Ahuja@student.uts.edu.au
}

Natalia Nikolova

University of Technology Sydney

natalia.nikolova@uts.edu.au

\author{
Stewart Clegg \\ University of Technology Sydney \\ stewart.clegg@uts.edu.au
}




\begin{abstract}
In this article we explore what happens in professional formation when the locus of its meaning, as it has been formed, is increasingly contradicted by professional practice. Specifically, we explore the problematic nature of architects' professional identity that is constituted in terms of the primacy of design aesthetics, in contexts where practice denies this identification. We highlight the tensions between identity and practices and suggest that while architects' traditional self-identification enables perpetuation of the profession's identity, it challenges the profession's standing in its relations with other professions and occupations. We refer to this as a paradox of identity. Although much has been written about the profound changes occurring in professional practices and professional jurisdictions, scant attention has been given to the ways in which professionals shape their identities in the context of changing practices. We conducted a year-long ethnography of contemporary architects engaged in large and complex projects in order to examine both the architects' and the profession's identity. Our contributions are threefold. First, we conceptualize misalignments between professional identity and professional practice as identity paradox that has consequences for identity work among professionals. Second, we highlight how professional identity construction is organized around competing and paradoxical identification. Third, the paper contributes to sociological studies of architecture by generating insights about the identity work of architects engaged in large multi-organizational projects.
\end{abstract}

Keywords: architecture; design; professional identity; professional practices; identity paradox; professional service firm 


\section{Introduction}

Amongst the professions, while law is considered predominately normative in nature and engineering draws on a scientific body of knowledge (Malhotra and Morris 2009), architects have traditionally viewed their profession largely as artistic (Cuff 1991; Deutsche 1996) and creative, with creativity being linked to design and style (Blau 1987; Gutman 1988; Kornberger, Kreiner, and Clegg 2011; Larson 1993). Perceptions of creativity in architecture build on the idealization of individual genius and a unique design 'signature' viewed as a personality characteristic (Blau 1987; Defillippi, Grabher, and Jones 2007; Heynen 2012). The emphasis on individual talent and design rather than on architects' demonstrations of 'objectively how they increase the value of projects that they design' (Gray 2014: 148) has led to a mismatch between professional practice and professional identity formation: while many architects aim to be successful designers (Gutman, 1997, 2010), in fact, few will practice this identity.

Prior sociological studies of architecture recognize that many architects prefer to practice by themselves (Gutman 1988; Cuff 1999). The growth of large-scale architectural practices however, means that architectural firms are increasingly subjects of and subject to the usual processes of organizing identified in the organization and management literature as 'bureaucracy' (Clegg, Harris, and Höpfl 2011): those mechanisms governing bureaucratic social, economic, and political processes (Pelkonen 2012). In such contexts the wide range of services and projects that large firms undertake create high profitability and employment of diverse architectural design expertize in good economic times but they also heighten identity 'dilemmas involving bureaucracy and professionalism and architecture and 
business' (Blau 1987: 143). These dilemmas pit conceptions of architecture as a designinclined aesthetic against the market-oriented 'business' practices of large-scale professional service firms. By virtue of their employment in large firms, the role of the architect has been changing and becoming more engaged and dependent on other cognate professions in large multi-organizational projects (Deamer 2010; Tombesi 2010).

However, while considerable empirical research has documented the changes in professional archetypes (Faulconbridge and Muzio 2009; Suddaby, Gendron, and Lam 2009), 'what is largely missing, then, is an understanding of how differently situated professionals account for the work they do in their changing contexts, both in terms of what they see as its fundamental purpose and how they see it as being enacted on a day-to-day basis' (Cohen et al, 2005: 776). In this paper, through a close examination of actual practices augmented by open-ended interviews, we uncover the divisions and tensions between architects' professional identity and practices. Our focus is on architects engaged in large and complex contemporary urban renewal projects, hereafter referred to as city building projects. For architects operating in this context the traditional professional identity inculcated in faculties of Architecture, centered on aesthetic design as creative practice (Cuff 1991; Fisher 2015), sits uneasily in a vastly different organizational context to that of the sole practitioner or small partnership.

Applying an extreme case methodology (Flyvbjerg 2006) we make three significant contributions. (1) We show how the context of city-building projects exacerbates professional practice tensions relating to creative, professional and managerial identity. Other studies have focused on the ways in which professionals resolve such tensions. They 
may do so by adapting their identity scripts to new identities (Bévort and Suddaby 2016); developing an identity that spans differences (Gurrieri 2012); claiming a meta-identity that addresses paradoxical aspects of identity (Gotsi et al. 2010); adopting multiple identities (Paton and Hodgson 2016). (2) By contrast, our research demonstrates how professionals' failure to find a way to adapt to multiple and conflicting identities can lead to their marginalization and alienation, which prevents architects and architectural associations from embracing positive aspects of a transforming identity. (3) We contribute to the sociology of architecture by generating insights about the identity work of architects engaged in large multi organizational projects.

Our article proceeds as follows. We first turn to the sociological literature on professional identity and architects' identity to situate the research theoretically. Second, we discuss our methods and findings in which we illustrate the tensions that pervade the identity work of architects. Third, we propose paradox theory as a lens for understanding these tensions, highlighting how identity construction is organized around competing and paradoxical identification before concluding with a discussion of our key insights, significant contributions and the implications of this research.

\section{Professional Identity}

Identity construction (Pratt, Rockmann, and Kaufmann 2006) and identity work (Sveningsson and Alvesson 2003) provide the key theoretical frameworks for understanding professional identities. Identity construction is defined as the processes through which a profession comes to be defined while identity work or identification (Alvesson and Willmott 2002; Ashforth and Schinoff 2016) is referred to as occurring at 
the individual level of identity construction. This paper adopts an interpretivist orientation to identity scholarship because it emphasizes the dynamic and recursive nature of identity construction (Ashforth and Schinoff 2016). The process of identity construction is constituted by many discourses, including those emanating from professional formation and wider social perceptions of this formation. Individuals are motivated to construct identities that they can view as stable (Ashforth and Schinoff 2016), valuable (Petriglieri 2011), coherent and distinctive (Alvesson and Willmott 2002). Moreover, individual identities are the result of a complex interplay between contexts, roles and individual characteristics (Petriglieri 2011). Roles, as devices, signify and condense meanings in identity construction (Simpson and Carroll 2008). As Mangen and Brivot (2015: 665) explain, 'an individual's professional identity is their self-concept defined by their role as an organizational member'.

Historically, higher levels of prestige and autonomy have been bestowed on professionals than other occupational groups because of their claims to unique knowledge and skills (Larson 1977; Blau 1987). In particular, established professionals (Kyratsis et al. 2016) such as doctors, lawyers, engineers and architects, have many common characteristics ascribed to their professional formation, such as lengthy formal education and codified behavior, as well as state and professional regulation. These characteristics clearly articulate a professional status or sense of 'being'. As Alvesson and Willmott (2002: 630) suggest 'education and professional affiliation are powerful media of identity construction'. In addition, professionals are defined by what they do, by practice (Pratt, Rockmann, and Kaufmann 2006) as well as membership of a professional group (Barbour and Lammers 
2015). The dynamics relating 'doing' and 'being' signify the identity construction of professionals in terms of the alignment between practice (contents and processes) and identity (Pratt, Rockmann, and Kaufmann 2006: 255). Being enables understanding of the self as one whose specific practices require specific tools and devices used for a particular purpose (Sandberg and Pinnington 2009). In other words, being has not only corporeal but also socio-material elements. The socio-materiality of being an architect, as with other professionals, is inculcated during long training and licensure requirements (Brown et al. 2010; Cuff 1991). Pratt, Rockmann, and Kaufmann (2006: 328) suggest that as a result of their 'semi-standardized' training, all doctors have some values and beliefs in common and thus have a generalized professional identity. Architects go through similar processes of professional identity formation that in their case involves familiarization with central practices of design and devices such as computer-aided design.

While identity has become a particular focus in studies of professions (Dent and Whitehead 2002), prior research does not adequately address the ways in which professionals shape their daily work practices and their identity (Ibarra 1999; Pratt, Rockmann, and Kaufmann 2006; Wallenburg et al. 2016). Bévort and Suddaby (2016) demonstrate how the new logic of managerialism changes accounting work and thus challenges the identity of accounting professionals in a study of accountants working in global professional service firms. We seek to build upon Bévort and Suddaby's (2016) study by focusing more closely on the nature of tensions and contradictions professionals experience when facing paradoxical identity demands. Our study provides an in-depth account of the tensions in identity work of architects triggered by changes in their professional practices. This research proposes that these tensions can be usefully understood through a paradox lens (Gotsi et al 2010; 
Gurrieri 2012) as paradox theory provides a framework for understanding complex and contradictory interrelationships (Clegg, Vieira, and Cunha 2002; Lewis 2000). In particular we note, 'paradoxes emerge when beliefs or assumptions fail to keep up with external changes' (Cannon 1996 cited by Lewis 2000: 766).

\section{Architects' identity}

The ethos of design as distinctive self-expression is highly disciplined and 'internalized in the professional socialization of many architects' (Brown et al. 2010: 530). Architectures' highest accolade, the Pritzker Prize, honors the hero architect, reinforcing the 'mystique of architectural authorship' (Heynen 2012: 338). For twentieth century sociologists, design as creative practice (Blau 1987; Gutman 1988; Larson 1993) is at the core of the profession's self-understandings. More recent organizational accounts have reiterated its place as a supreme value (Brown et al. 2010; Kornberger, Kreiner, and Clegg 2011). In other words, the image of the architect-as-lone genius, akin to Howard Roark in Ayn Rand's novel The Fountainhead (1943), is still tacitly embedded throughout the profession (Cuff 2012; Pelkonen 2012; Wiscombe 2006). The phenomenon of the star architect is the contemporary variant of this ideal (Grubbauer and Steets 2014; McNeill 2009).

Images do not always represent realities. Architects, in common with other professions, face increased pressures to become 'more managerial and bureaucratic to meet the demands for greater efficiency generated by growing competition and deregulation' (Malhotra and Morris 2009: 901). In the three decades since seminal studies of architectural profession (Blau 1987; Cuff 1991; Gutman 1988; Larson 1993), architectural practice has evolved 'from the auteur to the multinational full service firm' (McNeill 2009: 3). Many architects 
feel ambiguous about their identity, expressing ambivalence about the centrality of the aesthetics of design (Gutman 1997, 2010; Symes, Eley, and Seidel 1995) in contexts in which, practice denies this identification. Representations of the architect, in an increasingly multi-disciplinary and competitive business milieu however, remain underdeveloped (Bernstein 2010; Cuff 1999). In the case of transport infrastructure projects for instance, which are commonly engineering led, the traditional pyramidal structure of architect (on top), followed by engineering and construction (AEC) is upended because design has become 'operationally specialized' in distinct professional competencies (Tombesi 2010: 122). In this context, design entails a range of diverse expertise from specialist technical consultants, manufacturers and fabricators that provide particular services. Moreover, design as well as financial and contractual responsibilities are shared amongst various players (McNeill 2009) in the AEC team.

We contend that significant changes in the nature of architectural work are exemplified in large-scale urban redevelopment projects, which include transport infrastructure projects. Architectural firms increasingly enter into joint ventures and alliances to bid on these projects (Cuff 1999). Signature design firms are engaged to provide the design intent while other, mostly local architectural firms, take responsibility for the delivery of construction documents (Burr and Jones 2010; Cuff 1999). In other words, architects do not design an architecturally conceived totality (Deamer 2010). The focus shifts from design of a building to designing projects in which 'the division of labor in design is now socially spread' (Tombesi 2010: 122) to various members of the AEC team. City building thus requires a different model of practice, compared to that which has previously been examined (Bernstein 2010). 
While professional organizations have been identified as sites of transformative change over the past two decades (Bévort and Suddaby 2016; Thomas and Davies 2005), architectural firms have also undergone significant changes, due in part to increased pressures of bureaucratization and managerialism as well as to the increasing complexity of city building projects and the client relations entailed. Notably, there remains a paucity of studies in this professional setting particularly vis-à-vis the roles of contemporary architects in large-scale professional organizational practice (Burr and Jones 2010). In response, our research explores how architects engaged in city building projects, perform and talk about their everyday work. We draw on an ethnographic study of two large architectural firms rife with paradox at multiple levels, to which we turn next.

\section{Methods}

We use city building as an 'extreme case' of the phenomenon of change in the nature of the professional work of architects, that enables us to gain 'exemplary knowledge' (Thomas 2011: 515). City building becomes the prism through which changing facts and concepts in professional practices are viewed and studied (Thomas 2011). A case-oriented approach to an extreme example of practice allows an in-depth look at the complex interactions of many factors and offers a rich explanatory narrative. More information is gained because such projects activate 'more actors and more basic mechanisms in the situation being studied' (Flyvbjerg 2006: 229). In particular the advantage of extreme case typology is that it affords a close-up view of complexities and contradictions in real-life situations as they unfold in practice, thereby allowing the researcher to capture the rich ambiguity of the issues at hand (Flyvbjerg 2006; Thomas 2011). 
The architectural firms selected for the present research were chosen because of their size and the diversity of projects undertaken. Access was gained to two large, globally operative architectural firms. Both firms have been established for over fifty years and have won numerous national and international architecture awards. They have offices in several locations worldwide. Each firm is owned and led by $25-32$ directors or principals. They employ around 700 to 900 staff each, globally. Both firms are renowned as 'strong idea firm[s]' (Larson 1993: 100) and all the owners are also leaders of the firms and share an equal status. The distinctive structure of ownership and authority are seen as a key-defining characteristic of these organizations (Hinings, Brown, and Greenwood 1991; Pinnington and Morris 2002). Both firms are multidisciplinary professional service firms, as their services encompass the disciplines of architecture, urban design, interior design and landscape architecture, although architecture was the dominant profession both in terms of the organizations image and fee earnings.

We adopted an ethnographic methodology (Bévort and Suddaby 2016) because it enables a close observation to the day-to-day activities of architects. Data were collected through observations, informal interactions and shadowing (Vough 2012). Observation included meetings with consultants and stakeholders, as well as internal team meetings, participation in site visits, design meetings, presentations and management meetings. The first author had a hot desk in the open plan offices from which she was able to observe the daily work activities of around 100-140 people in each firm. The observations commenced in July 2015 and concluded in June of 2016. In addition, informal and open-ended conversational interviews were conducted with forty-eight architects (Table 1) to augment direct observations (Cuff 1991). As such, the data presented in this paper is not garnered from 
formal interviews and stems mostly from participant observation and informal conversations (Siciliano 2016). The informal open-ended questioning canvassed the participant's career history, the work they do on a daily basis, their perceptions of what architecture is about, the extent to which they felt the work of architects is changing and their perceptions of managerial and professional roles and responsibilities in their organizations. Varying levels of seniority and experience were distributed across the men and women, of different ages and experience, who engaged the researcher in conversations typically lasting between one and one-and-a-half hours. The informal conversations were recorded, when possible, and transcribed verbatim to ensure reliability (Gotsi et al. 2010). A field journal was used to highlight interesting quotes and patterns. Additionally, the first author shadowed a director, a senior associate and a graduate architect. The shadowing activity commenced in September of 2015 and ended in March of 2016. The first author was responsible for all data collection. As a practicing architect, she was able to gain access readily. The second and third authors did not have such access and represent 'outsiders' as they do not share the world-view of the subjects, which counterbalances the possibility of 'going native' (see also Bévort and Suddaby 2016: 25).

\section{Table 1 about here}

Our analytic strategy adopted the two stage model described by Timmermans and Tavory (2012: 180) in which rather than setting aside all preconceived theoretical ideas, they direct the researcher to 'enter the field with the deepest and broadest theoretical base possible and develop their theoretical repertoires throughout the research process'. Data analysis was based on the 'logic of abduction' (Peirce 1934: 195). The analysis of the data proceeded 
through collective reading, re-reading and discussion of interview transcripts and field and meeting notes with the purpose of identifying how architects' creative and routine practices are constituted in a context marked by managerialism, interconnectedness with other occupations, and client power. We consider the implications of these changes for architects' identity.

We draw on the principles of grounded theory (Charmaz 2006; 2008) in looking at how identity is formed in professional practice in which the subjectivity of architects cannot be taken-for-granted or ignored (Alvesson 1990). Initial coding was open, allowing themes to emerge from the data. Early codes were used to direct and focus on further data collection. We iterated these analyses multiple times and compared findings to ensure that the codes were tightly grounded, moving back and forth between data and analysis (Orton 1997), connecting the in vivo codes to higher level abstract categories and examining these in light of theories that might provide explanatory power (Locke, Golden-Biddle, and Feldman 2008). The data were organized around major emergent conceptual themes (Gioia, Corely, and Hamilton 2012), as can be seen in Figure 2.

In what follows we analyze three discursive themes in which practitioners reveal the struggles and tensions that ensue from a complex interplay between the powerful discourses of architecture and management. These tensions shape the nature of their practices and present challenges for identity work. Building on the notion of struggle, special attention is placed on how respondents drew on competing discourses as they sought to shape and make sense of profound changes taking place in their professional practice. First, we discuss the tensions over design control. Second, we demonstrate the struggle for 
professional autonomy. Third, we illustrate how architects struggle to maintain an antagonistic stance between the ethos of design aesthetics and engagement in the construction process, under the rubric of identity paradox.

\section{Findings}

Figure 2 summarizes the process that we followed which shows our first-order codes, the second-order themes and overarching concepts. Specifically, the overarching concepts shown were the ones that best explained how changes to architects' practices influence identity construction and how identity based tensions have led to paradoxical identity.

\section{Figure 1 about here}

\section{Design control}

\section{a. Ambiguity of authorship}

In defining the design aesthetic of architectural work as its exemplary characteristic, the architect is seen as the 'designer-artist' (Blau 1987: 143) or 'master designer' (Deamer 2010: 83). However, this romance of the individual in architecture is outmoded in city building projects. As one project architect explained, 'there are 300 consultants working on this [project] over the various phases. It's hard to know who is actually making the decisions'. Architects occupy team-based roles in many building projects such as this, making dilemmas of design control even more pertinent, especially as large teams of architects employed by different architectural firms are responsible for different parts of the 
design. In this contemporary context, the authorship of the overall design is not easily attributable to a solitary figure. As a graduate architect explains:

"They [signature architects] did the design intent...I mean that's a really vague term ... but we were doing the 'actual designing' because we were working out the actual nuts and bolts... whether the gap was $2 \mathrm{~mm}$ or $3 \mathrm{~mm}$, how things were actually going to get built" (Jess, graduate architect).

In practice, designing is not a linear process. It is instead an iterative process in which many disparate specialist consultants including manufacturers and fabricators, for example, provide their expertize. There are many aspects to design, from design intent to the production of technical or working drawings in which structural and mechanical systems are integrated that require architects to manage and organize diverse contributions, giving design a significant organizational dimension. Significantly, the iterative nature of design poses difficulties in maintaining control over the design, as noted by this director:

“We don't like working with production architects because we are control freaks [laughs] well...we want to control the finer detail as well as the broader detail... designing isn't something we just do at the beginning then stop. It's a continuous process, right up until its built. So how can we hand it over?"

There are significant ambiguities of control over the design as it is interpreted in practice because the 'finer details' may not develop as planned. The development of the design sometimes results in substantive changes to the original, rather abstract, 'concept' that is intended only to guide the design rather than being an actual representation of the finished 
buildings. The complexities surrounding control of the design when architectural services are segmented in the construction process are particularly acute in large-scale city building projects. For instance, a director explained that their firm spent two years advising the client on what was called a 'reference design' that was intended to guide the subsequent iterations of the project design. However, the $\mathrm{D} \& \mathrm{C}$ (Design and Construct) team architects changed the reference design substantially, 'in an effort to get noticed' and many of the defining features of that initial design intent were lost. These extracts illustrate that the conception of design as the act of an individual architect is contradicted by the fact that design-in-practice is not a creative moment but rather, a prolonged, iterative, differentiated and collaborative process.

\section{b. Collaborative nature of design practices}

Historically, drawings were the medium for the projection of design ideas and the essential component of the definition of an architect. In city building projects however, design is more dynamic than merely being a stylistic interpretation of the building's purpose. As this architect notes:

“With these big projects there's huge numbers of people involved and so it's a different way of working. You know the old idea that the architect sits at the head of the table and draws everything and that's how you do it - it's [design] much more dynamic, much more dynamic" (Director).

In these comments the traditional understanding of an architect as the 'master-designer' is challenged. While control over design is considered central to the self-concepts of the 
architect, in practice, the ambiguities and complexities of control over aesthetics of design has consequences not only in terms of authorship of design but significantly for decisions that challenge the design intent. Typically, initial aesthetic considerations are heavily modified when initial estimates from contractors for various 'packages' are received. A commonly used term, 'value engineering', refers to the 'slash and burn' of design ideas and is a much dreaded process amongst architects. In this process design ideas are reconfigured and sometimes completely overthrown to meet the projects' commercial imperatives. Subsequently, architects prepare various 'options' based on discussions with members of the client and construction team. In other words, the material and economic choices made become a significant issue in the control of design processes. While recognizing that absolute control of design is not tenable in city building projects, architects nevertheless struggle against changes initiated by others, which are viewed as threats to the aesthetic integrity of the design:

"A lot of suggestions for changes come up during the process and we have to be kind of vigilant custodians [as a design architect] because everyone's got a reason to change it and ... I know it [design] can just drift... you have to push really hard to get to the people making the decisions... you've got to play that kind of game really or you just get walked all over and that's the difference in doing big complex projects" (Director).

A common theme in maintaining control of design is retaining engagement in the construction process in order to have continued dialogue regarding the implementation of design. However, this remains problematic as architects increasingly collaborate with other 
professionals in the provision of service packages for particular phases in the construction process. For instance, architects may be engaged in the early phases of the project to provide a concept design (design architects) or in the later stages to provide construction drawings (production architects). Moreover, different architectural firms may be engaged in different phases of a project. An associate sums up this tension: 'It's pretty crazy ... as you can imagine...it's hard enough for one firm to decide what to do let alone four firms collaborating'.

\section{Professional autonomy}

\section{c. Tensions concerning financial success}

Traditionally, domination of a domain of work is considered central to professional power; however, the emergence of large architectural practices and their employment in large-scale projects puts pressure on architects to do more managing and less designing. There is an increased recognition that business functions are important for the success of these practices. For example, while the prestige and reputations of architectural firms are built primarily on awards, publications and generally on recognition bestowed by esteemed peers, architects are acutely aware of the need to engage in projects that a client will fund. As one director explained, the commercial success of the firm is absolutely critical:

"The project is the center of our universe; we [the firm] don't exist if it wasn't for our projects so you have ultimately one principal who has to be responsible for the health of the project and its success financially". 
Financial success is seen as the ultimate goal, yet some architects still see design expression as a means to achieve professional recognition. Participants stated that they were 'fortunate that we are a profitable organization' as the commercial success of the firm enabled investment in its 'design' reputation. For example, design competitions are prized as a means of design freedom and although doing competitions is never profitable, the prestige in winning far outweighs the financial concerns. Thus, handing over of financial control to 'MBA types' was seen as detrimental and potentially constraining to design expression.

\section{d. Increased managerialism}

Our respondents strongly believe that they are responsible for building and nurturing client relationships, as demonstrated by the following comment:

"We the people who own it, front it, lead it [the firm] we do the deals, we know the clients, we haven't abdicated that responsibility of projects and the relationships" (Director).

Younger architects also noted that building networks is critical for their career: 'you don't get to be a director unless you bring in the work' (Associate). The concern amongst our participants was that handing over these roles to managers might not align with the interests of a creative, 'design-oriented' firm and the types of projects they wanted to pursue. The owners and directors want to be autonomous in the projects they chose to undertake while recognizing that 'there are commercial incentives to be profitable and everyone tries to make sure that they are [profitable]' (Director). Similarly, the total separation of the HR 
management function from architectural expertize also was a source of tension, as noted by this director:

“In the end ...no matter how great the HR support is who's going to judge [the creative talent] ... its gotta be us [owners of the firm] ...yeah I see all these kids coming out of university, how do you connect with them? It's not through a job description on a web site. There are more important ways of accessing talent".

Even though this firm has a sophisticated and mature practice model, these comments about letting go of the HR functions and therefore relinquishing control of 'accessing talent' for the firm are seen as an abdication of responsibility by the owners of the firm to 'spot the creative' talent or who is a 'good fit' for the firm. This architect notes that in order to connect with young talent a more personal connection with students coming out of universities is required because it outweighs the standardized procedures of applying for a job on the firm's website, which is handled managerially by HR. These comments demonstrate that architects are in a peculiar position. They struggle with ceding non-design elements of practice such as, business functions to others, because they are nonetheless crucial to the overall success of the firm.

\section{e. Managing overtakes designing}

The pressures to become more managerial, bureaucratic and to keep control over business functions to meet the demands for greater efficiency contradicts the 'notions of creative genius and of architecture as high art' (Blau 1987: 141). This is particularly visible in large architectural firms; there architects have limited opportunities for design in their daily 
routines because they regularly have to deal with 'fees, budgets, difficult management issues, resourcing meetings, performance reviews, problems on site and arguing with contractors over the quality of the built work' (Associate), issues that were traditionally considered non-architectural tasks. In practice however, an associate described his daily routine as 'managing the day from meeting to meeting'. Another senior associate explained that she spends her typical day in client presentations, consultant meetings, site meetings and office management meetings stating: 'I haven't done a drawing for over 10 years'. She explained that when she was at her desk she was usually responding to emails or checking drawings done by others. The vast arrays of non-architectural tasks that architects deal with in their daily routines were frequently referred to as 'cumbersome', 'things that have to be done' or 'burdens', as noted by this director:

"In a way you wanna relieve the burden of a lot of those areas that different owners are having to deal with at the moment. They can focus on just being architects and all those other things that aren't really to do with 'being' an architect, there's just to do with running a business and can be separated out and dealt with ...to some degree".

These comments reflect the tensions over 'being an architect' and 'running a business'. On the one hand, ceding control over business functions means 'being managed' by other 'MBA types'. On the other hand, retaining autonomy over business functions means that managing overtakes designing. We see tensions emerge over control of business functions and professional autonomy as architects struggle to align changes in their practices with an idealized professional identity. 


\section{f. Persuasive skills}

Many architects note that the realization of architectural designs calls for architects to engage in 'persuasive strategies' in order to convince clients and project managers of their expertize and thus, go beyond the emphasis on design expertize. Particularly in large projects, aesthetic supremacy is constrained by a myriad of exogenous forces including political whims and commercial imperatives. As this director states:

"The bigger the project the more things can go wrong and, uhm, the more persuasive you have to be and its only persuasion coz you don't hold the money".

The above comments exemplify two points. First, persuasive skills are seen as critical to exercise control over design. However, in professional education, primacy given to design as an aesthetic consideration means that, skill development in persuasive strategies are excluded from the dominant narrative forming practitioners in architecture. Second, architects' were traditionally viewed as the expert in design, which gave them their professional authority and defined their professional jurisdiction. However, dramatic changes in architects' practices in particular, the collaborative nature of design on city building projects, has led to the erosion of the architects' exclusive professional expertize. Thus, persuasive skills become critical in order to remain engaged in the design deployment processes. When asked how their firm retains integrity of design on these large projects, a director explains:

"I think you do it by... frankly by high level of engagement and, ehm, being an advocate for the outcomes and being at the table when those decisions are made so 
its a sort of different way of working [than on smaller projects] ...so it's really a process and you got to stay on top of it if you don't want the thing [project] to go completely pear shaped".

The emphasis in these comments on 'being at the table when those decisions are made' and 'high level of engagement' is particularly problematic because architects' services are frequently procured in distinct segments. Nevertheless, architects are increasingly engaged in providing convincing accounts of what they do, which suggests that rhetorical skills are increasingly significant for the organization of their activities, particularly for client relations (Alvesson 2001). In other words, negotiating outcomes throughout the project process requires more than the formal knowledge of the aesthetic and technical aspects of design. Many of our respondents stressed the need for every project to have 'a champion'. For instance, as this associate explains:

"Yeah with any project ... you need that champion who kind of digs their heels in... whatever the relationship is ...to kind of plead for what is important [in the design]".

In this account, the architect in practice is a multi skilled practitioner, with a high level of advocacy and negotiating skills, one who will 'stick their neck out' and rally for the integrity of the design throughout the project process. In other words, maintaining design control on city building projects is a complex process that requires a diverse range of business and leadership skills. Architects struggle to align the traditional definition of an architect as the individual-who-designs, with the changing nature of their practices. 


\section{Identity paradox}

\section{g. Being powerful and in control}

Paradoxically, despite the changes in architectural practices, which have led to tensions over control and autonomy, architects perceive themselves as powerful and in control in their self-conceptions:

"I am constantly amazed at how powerful the architect is because its only us that can give a physical manifestation... honestly those things are frozen jammed cogs! Until the architect draws something up" (Director).

In these comments the architect is depicted as 'powerful' and important to the translation of design ideas, as they bring materialization to 'frozen jammed cogs'. Architects continue to see themselves as being the dominant actor in the construction process, as noted in this comment:

"I mean when I look at younger architects ... there's this kind of thing ' well you know I'm saying it and they've just gotta do it!' and we go 'well... it's not going to work like that!" [laughs] (Senior associate).

By continuing to view themselves as autonomous designers, architects miss the opportunity to re-define their identity in alignment with the changing nature of their practices. In addition, they find it extremely difficult to demonstrate the value they create. As this architect explains: 
"We talk better to each other than we can to a public audience ... I think so many architects regard themselves as poets... and there's not an appetite out there... in the public consciousness for that sort of poetry" (Senior associate).

\section{h. Under-valued and marginalized}

With architectural services increasingly fragmented and the proliferation of specialist consultants, design managers, construction managers and projects managers, many architects noted that the aesthetic dimension of architectural work is under-valued. In our data, architects struggle to be valued for the work that they actually do. In particular, misalignments between being and doing are construed as marginalization of architects in the construction process. Participants expressed concern that the role of the architect is 'under threat' as 'it's getting chopped up further and further and the boundaries of what an architect does is blurring more and more'. Project architects talked about the need to 'stand your ground' and 'push back' when design decisions were challenged by others on the AEC team, because as this architect notes:

“Everybody's got a reason 'oh change this and it won't hurt!' but everything is so interconnected and so we're the people [architects] who know that" (Associate).

These accounts highlight the struggles that ensue during the design deployment and construction processes in which challenges to design decisions are based on costs or technical issues. As one project architect stated: 'If the problem is to save money' then we'll prepare 'compromise options' or solutions that 'don't undermine the design thinking' but these are often overlooked or disregarded in a 'bid to save money'. In these comments 
the architects' self-image is challenged, leading to talk about being 'alienated' and 'marginalized in the construction process'. Misalignment between self-concepts and practice are also reflected in the following comments in which the integrity of these selfconcepts is called into question:

"You know off course we don't get enough credit for it [work that we do] ... as everyone thinks they are the most important person in the room" (Director).

In this account, the frustration at the lack of recognition of the work that architects do highlights the disjuncture between the identity and practices and its significance. Additionally, these comments draw attention to professionals' vulnerability where the changing nature of architectural work destabilizes the professionals' traditional identity. This misalignment between identity and practices has led to the marginalization and alienation that many architects describe.

\section{Discussion}

The research examined the identity work engaged in by architects as they attempt to negotiate the tensions and contradictory pressures in the performance of their professional identity. Notably, the changing nature of architectural work in city building projects has led to an erosion of identity based on aesthetic supremacy while management practices and skills have become critical. Prior research has recognized that identity work is heightened in response to these tensions particularly in the creative industries (Beech et al. 2012; Elsbach and Flynn 2013; Gotsi et al. 2010; Hackley and Kover 2007) and that identity based dilemmas have several related manifestations (DeFillippi 2009; Jarzabkowski, Lê, 
and Van de Ven 2013). Our research connects disparate pieces of professional identity construction that other theories have offered and we provide further insights into the complex interplay between professional identity and professional work and how these tensions are revealed, negotiated and sometimes silenced (Brown et al. 2010). In the following, we use paradox theory as a lens for understanding dialectic tensions that pervade identity work of professional architects in the marketplace. Individuals formulate paradox when dialectic tensions and contradictions emerge through processes of reflection or interaction (Gurrieri 2012). In particular, paradox literature offers strategies for accommodating the need of professional workers to manage multiple and conflicting identities (Gotsi et al. 2010). As such, prior research has 'highlighted the utility of a paradox lens in understanding divergent and disruptive experiences and managing contradictions and their associated outcomes' (Gurrieri 2012: 801; Gotsi et al. 2010).

We contend that the romantic anachronism of design as individual talent (Blau 1987), limited to the domain of aesthetics, is constraining as it offers 'limited subject positions from which only certain identities can speak' (Ainsworth and Hardy 2004: 166). This limited understanding of design creates paradoxical tensions that shape individual identity construction (Cuganesan 2016). In the case of architects, knowledge creation takes place not only in 'becoming' through institutions such as professional communities and higher education but also in 'being', by 'doing' in cooperation with clients and consultants. In terms of actual practice the latter is more important. Despite long training and licensure requirements, the professionalization of architects through an ethos, ideology and identity of design aesthetics does not resonate with the practices of architects in large multiorganizational projects. There are specific 'non-architectural' skills required to engage 
meaningfully in the design deployment processes; for instance, the use of persuasive strategies to advocate the quality of design outcomes. These particular skills rely largely upon the architect's ability to talk convincingly to a diverse audience, creating challenges for architecture as a practice. Architects that refrain from strategically engaging with the changing nature of their work and developing new identities that can strengthen their position vis-à-vis clients and other professions will lose out. Particularly in city building projects, clients frequently influence and control the process of production of architectural services, thereby compounding the uncertainties of the nature of professional work while significantly dominating their practices. As they are being formed in professional schools, architects are uniquely creative (Blau 1987; Cuff 1991); in practice, however, they juggle issues of management for which they have had little or no professional preparation or role models (Ibarra 1999).

The way in which architects are viewed as professionals in the wider social context of construction projects and their socio-political arenas is important because of the way these views act as resources for identity construction, highlighting the complexities of maintaining a positive identity as a protective ideology (Brown 2015) in the face of changing practices. While a select few 'starchitects' (McNeill 2009) occupy a mythical status in their public personas, in our data architects often referred to their work as being 'under-valued', suggesting vulnerability and insecurity incommensurate with their identity as an elite professional group. For as Brown and Coupland (2015) argue, professional workers self-define in terms of what they do and consider themselves engaged in prestigious work in which they have significant autonomy. The professional autonomy of architects however, is increasingly constrained by team-based roles, demanding clients, and 
increased managerialism. The confusing implications of this can be observed in the identity work of architects for whom the design aspects of their work that dis-identifies them from managerial identities also provokes anxieties about being undervalued and misunderstood in a professional capacity. Our first key contribution is to foreground paradoxical identity tensions that arise from misalignments between understandings of an entrenched professional identity and those being forged in professional practice. Our study demonstrates that significant changes in architects' practices on city building projects have led to the diminution of the architects' professional expertize associated solely with design. Consequently, architects struggle with ambiguities of design control and tensions related to historic understandings of professional power and autonomy.

While a solid 'sense of self as creative' has long been acknowledged as crucial to the creative workers identity (DeFillippi 2009), prior research investigates identity dilemmas which, through processes of successful identity work, lead to a resolution (Beech et al. 2012). For example, Hackley and Kover (2007) suggest that advertising workers constantly negotiate their identities in order to align their self-concepts with external groups and institutions. On the other hand, Gotsi et al. (2010) suggest that developing a meta-identity as 'practical artists' is a strategy through which creative workers accommodate multiple and conflicting identities. In the medical context, Joffe and MacKenzie-Davey (2012) argue that a hybrid identity, that of the 'medical director', helps maintain medical identity while simultaneously distinguishing the doctor from a negatively construed managerial identity. In particular, established professionals such as physicians, where existing identities are deeply entrenched, appear to face distinct identity challenges such as professional values conflict and a perceived loss of status, associated with reorganization of professional work 
(Kyratsis et al. 2016). In these studies identity work is seen as seeking to manage the conflicts that arise from paradoxical tensions (Kreiner, Hollensbe, and Sheep 2006; Mallet and Wapshott 2012; Kyratsis et al. 2016).

Our analysis of how individual architects deal with multiple and competing identities at work contradicts these studies. We suggest that architects struggle to balance these conflicting identities because their professional identity is deeply and existentially anchored in the supremacy of design aesthetics (Styhre and Gluch 2009). Moreover, we suggest that in response to paradoxical identity demands (Jarzabkowski, Lê, and Van de Ven 2013) architects explicitly dis-identify from their managerial identities while simultaneously enacting managerial practices, thereby exacerbating identity tensions that remain unresolved. Such separation has been seen as delusional and unhealthy for wellbeing in the long term (DeFillippi 2009). Other studies have noted that defensive responses by actors escalate contradictions whereas active responses to paradoxes defuse contradictions by accepting the paradox (Jarzabkowski, Lê, and Van de Ven 2013). Significantly, active responses do not aim to resolve the paradox but instead, provide ways to work within it (Lewis 2000). Moreover, identifying and understanding opposite and simultaneously occurring tensions as co-existing and interwoven helps reframe paradox as two sides of the same coin (Gotsi et al. 2010) rather than as polarized conflicts. Prior research has adopted a paradox lens in order to reframe dialectic identity tensions by accommodating these tensions, rather than resolving them per se (Gotsi et al. 2010; Gurrieri 2012; Lewis 2000). Our findings extend these studies by highlighting the feelings of 'stuckness' (Jarzabkowski, Lê, and Van de Ven 2013) that ensue when identity tensions are left unexamined. In our 
study, practitioners expressed their struggles as erosion and fragmentation of professional expertize, being undervalued, marginalized and alienated in the construction process. Our second contribution is thus to enrich the understanding of professional identity construction by focusing on the tensions between identity and practices, in particular, by focusing on paradoxical demands of being professional architects and doing professional work.

Our final contribution is to extend the sociological understandings of architecture by generating insights about the complexities of identity work of architects engaged in large multi-organizational projects. Our research interest is in the micro-level of identity construction because it reveals fascinating identity disjunctures and struggles. This paper explores the individual subjectivity of architects by focusing on how opposing tensions between professional and design identity play out in day-to-day work, to generate insights about the identity construction of professional in the marketplace. In doing so we attend first, to Bévort and Suddaby's (2016) call for more empirical consideration of how individual professional identities are enacted. While it has been argued that professionals derive a large-part of their self-understandings from the work that they do (Pratt, Rockmann, and Kaufmann 2006; Brown and Coupland 2015), our analysis reveals that the work of the architect in city building projects varies a great deal and that, in general, management tasks are construed negatively. Second, we suggest that increasing misalignments between work and identity sees architects revert to the apparent safety of a historic and almost mythical 'strong identity' - the 'omniscient design expert' (Ross 2010: 9). Here, they echoed Lewis' (2000) observations that regression to the norms of the past serves to temporarily protect actors from recognizing that extant skills and understandings maybe obsolete in their present and future work. We argue that the ideology embedded in 
professional identity excludes the development of new, strong identities and thus restricts the 'definition of core capabilities that can be used for competitive advantage' (Glynn 2000: 287). In other words, while 'doing' on city building projects is increasingly defined by teamwork, specialist technical skills and significantly the ability to share, not just lead the design process, the professionals' identity constructed as an individual designer restrains developing new identities, perhaps ones that embrace the management and organization of design more creatively and actively. As such, we build upon the studies that delve deep into the profession of architecture (e.g. Blau 1987; Cuff 1991; Gutman 1988; Larson 1993) by drawing on accounts of individual architects in the organizational context of large multidisciplinary professional service firms. Although these studies have emphasized the fact that architectural practice is driven and structured by powerful forces that have little to do with design aesthetics (McNeill 2009), our study is unique by offering insights into the extent to which traditional identity of a professional architect continues to resonate (if indeed it ever did), in the identity work of contemporary architects. Specifically, our analysis demonstrates a significant but under studied role of individual subjectivity in the enactment of professional identities 'on the ground'.

There may well be wider implications to be drawn from our study but limitations that merit attention before doing so should be considered. First, the data focuses on a particular profession and different professions face various levels of control and conflict. A broader array of professional practice might generate different findings. For instance, the role of the medical director, developing as a response to organizational changes in hospitals would make for an interesting comparison for further empirical research; research, however, that is beyond the focus of this paper. 
Second, there are many different ways of being an architect. For instance, '[a]rchitects from Vitruvius to Walter Gropius have conceived of their profession as art and science' (Cuff 1992: 204) and there are strong traditions of technical and material expression in architecture (Curtis 1996), and thus the concept of collaborative practice is hardly new. However, while new technologies and new materials provide architects with novel opportunities for greater levels of collaborations they also exacerbate tensions regarding who ultimately controls processes of design (Stern 2010).

Third, we do not claim that our findings, and the implications that flow from them are universal: even within architecture there are practitioners that may find no contradictions in their professional identity. This might be particularly the case for smaller architectural practices where architects might develop hybrid identities early on. However, architects engaged in large, complex multi-organizational projects, represent an entirely new model of practice and lack satisfactory resources with which to forge a rich sense of identity premised on the traditions of the field. Today, even a sole practitioner is not likely to be a completely isolated professional and thus will encounter some struggles of control over design and business functions vis-à-vis client whims and economic cycles. These limitations underscore the need for more nuanced approach to professional identity construction. Despite these limitations our data is useful because it provides a rich, textured insight into the work of professionals in their changing context and these insights should be valuable in the study of other professions where field level changes in practices have important implications for professional identity. 


\section{Conclusion}

Our findings highlight that a limited understanding of the nature of professional work and practices is potentially destructive because it reinforces an outmoded conception of autonomy in professional identity construction. The tension between aesthetic values and commercial reality results in a struggle to maintain a sense of professional identity that is riven by the fault lines dividing professional ideology and professional practice. This misalignment has implications for the subjective identity work of individual professionals as it creates complex tensions that have negative affects on the self-concepts of professionals. We suggest that the nature of the contradictory tensions must be identified and understood by processes of critical reflection. These tensions generate the necessary friction required to stimulate reflection, debate and potentially generate a shift in identity construction. However, there remains a lack of satisfactory resources for forging a rich sense of professional identity. Notably, alienation and marginalization in the construction process are amongst the experiences of this misalignment between identity and practices of architects. The challenges for professionals are to reframe creatively the relationship between contradictory elements of their professional identity and practices, such that their intrinsic oppositional nature is understood and accommodated without compromising either pole.

This article contributes to a more sophisticated understanding of professional identity in three respects. First, we extend the metaphor of identity as struggle by highlighting two arenas of tensions where identity disjuncture occurs because the traditional professional identity is at odds with professional work and we draw attention for the need to develop a 
nuanced approach to professional fields where disparate rationalities are contested.

Second, we contribute to sociological studies on architecture by highlighting the identity tensions architects practicing in large-scale architecture firms experience. Third, although we have focused on architects in this paper, our insights should be valuable in the study of other professionals where field level changes have important implications for professional identity.

\section{References}

Ainsworth, S. and Hardy, C. (2004) 'Discourse and Identities'. In Grant, D., et al. (eds.) The Sage Handbook of Organizational Discourse. London: Sage, pp. 153-74.

Alvesson, M. (1990) 'On the Popularity of Organizational Culture', Acta Sociologica, 33(1), pp. 31-49.

Alvesson, M. (2001) 'Knowledge Work: Ambiguity, Image and Identity', Human Relations, 54(7), pp. 863-86.

Alvesson, M. and Willmott, H. (2002) 'Identity Regulation as Organizational Control: Producing the Appropriate Individual', Journal of Management Studies, 39(5), pp. $619-44$.

Ashforth, B. and Schinoff, B. (2016) 'Identity Under Construction: How Individuals Come to Define Themselves in Organizations', The Annual Review of Organizational Psychology and Organizational behaviour, 3, pp. 111-37.

Barbour, J. and Lammers, J. (2015) 'Measuring Professional Identity: A Review of the Literature and a Multilevel Confirmatory Factor Analysis of Professional Identity Constructs', Journal of Professions and Organization, 2(1), pp. 38-60.

Beech, N., Gilmore, C., Cochrane, E. and Greig, G. (2012) 'Identiy Work as a Response to Tensions: A Re-narration in Opera Rehersals', Scandinavian Journal of Management, 28, pp. 39-47.

Bernstein, P. G. (2010) 'Models for Practice: Past, Present and Future'. In Deamer, P. \& Bernstein, P.G. (eds.) Building (in) the Future: Recasting labor in Architecture. New York: Princeton Architectural Press. 
Bévort, F. and Suddaby, R. (2016) 'Scripting Professional Identities: How Individuals Make Sense of Contradictory Institutional Logics', Journal of Professions and Organization, (3), pp. 17-38.

Blau, J. (1987) Architects and Firms: A Sociological Perspective on Architectural Practice. Cambridge MA: MIT Press.

Brown, A. (2015) 'Identities and Identity Work in Organizations', International Journal of Management Reviews, 17, pp. 20-40.

Brown, A. and Coupland, C. (2015) 'Identity Threats, Identity Work and Elite Professionals', Organization Studies, 36(10), pp. 1315-36.

Brown, A., Kornberger, M., Clegg, S. and Carter, C. (2010) 'Invisible walls' and 'Silent hierarchies': A Case Study of Power Relations in an Architectural Firm', Human Relations, 63(4), pp. 525-49.

Burr, K. L. and Jones, C. B. (2010) 'The Role of the Architect: Changes of the Past, Practices of the Present, and Indications of the Future', International Journal of Construction Education and Research, 6(2), pp. 122-38.

Charmaz, K. (2006) Constructing Grounded Theory: A practical Guide Through Qualitative Analysis. London: Sage.

Clegg, S., Harris, M. and Höpfl, H. (eds.) (2011) Managing Modernity: Beyond Bureaucracy? Oxford: Oxford University Press.

Clegg, S., Vieira, d. and Cunha, M. (2002) 'Management Paradoxes: A Relational View', Human Relations, 55(5), pp. 483-503.

Cohen, L., Wilkinson, A., Arnold, J. and Finn, R. (2005) 'Remember I'm the bloody architect!' Architects, Organizations and Discourses of Profession', Work, Employment \& Society, 19(4), pp. 775-96.

Cuff, D. (1991) Architecture: The Story of Practice. Cambridge: MIT Press.

Cuff, D. (1992) 'Divisive Tactics: The Design-Production Practices in Architecture', Journal of Architectural Education, 45(4), pp. 204-12.

Cuff, D. (1999) 'The Political Paradoxes of Practice: Political Economy of Local and Global Architecture', Architectural Research Quarterly, (3), pp. 77-88.

Cuff, D. (2012) 'Introduction: Architecture's Double-Bind'. In Crysler, C.G. \& Hilde, H. (eds.) The Sage Handbook of Architectural Theory. London: Sage, pp. 385-93. 
Cuganesan, S. (2016) 'Identity Paradoxes: How Senior Managers and Employess Negotiate Similarlty and Distinctiveness Tensions over Time', Organization Studies, pp. 1-23.

Curtis, W. (1996) Modern Architecture: Since 1900. 3rd edn. London: Phaidon Press.

Deamer, P. (2010) 'Design and Contemporary Practice', in Cuff, D. \& Wriedt, J. (eds.) Architecture From the Outside In: Selected essays by Robert Gutman. New York: Princeton Architectural Press.

DeFillippi, R., Grabher, G. and Jones, C. (2007) 'Introduction to Paradoxes of Creativity: Managerial and Organizational Challenges in the Cultural Economy', Journal of Organizational Behavior, 28, pp. 511-21.

DeFillippi, R. (2009) 'Dilemmas of Project Based Work: Contexts and Choices', Journal of Media Business Studies, 6(4), pp. 5-30.

Dent, M. and Whitehead, S. (eds.) (2002) Managing Professional Identities: Knowledge, Performativity and the 'new' Professional. London: Routlidge.

Deutsche, R. (1996) Evictions: Art and Spatial Politics. Cambridge: MIT Press.

Elsbach, K. and Flynn, F. (2013) 'Creative Collaborations and the Self-Concept: A Study of Toy Designers', Journal of Management Studies, 50(4), pp. 515-44.

Faulconbridge, J. R. and Muzio, D. (2009) 'The Financialization of Large Law Firms: Situated Discources and Practices of Reorganization', Journal of Economic Geography, 9, pp. 641-61.

Fisher, T. (2015) 'Labour and Talent in Architecture', in Deamer, P. (ed.) The Architect as Worker: Immaterial Labor, the Creative Class, and the Politics of Design. London: Bloomsbury.

Flyvbjerg, B. (2006) 'Five Misunderstandings About Case-Study Research', Qualitative Inquiry, 12(2), pp. 209-45.

Gioia, D., Corely, K. and Hamilton, A. (2012) 'Seeking Qualitative Rigor in Inductive Research: Notes on the Gioia Methodology', Organizational Research Methods, 16(1), pp. 15-31.

Glynn, M. (2000) 'When Cymbals Become Symbols: Conflict over Organizational Identity Within a Symphony Orchestra', Organization Science, 11(3), pp. 285-98.

Gotsi, M., Andropoulos, C., Lewis, M. and Ingram, A. (2010) 'Managing Creatives: Paradoxical Approaches to Identity Regulation', Human Relations, XX(X), pp. 125. 
Gray, K. D. (2014) 'A Value Proposition', Perspecta, The Yale Architectural Journal, Money, pp. 147-54.

Grubbauer, M. and Steets, S. (2014) 'The Making of Architects: Knowledge Production and Legitimation in Education and Professional Practice', Architectural Theory Review, 19(1), pp. 4-9.

Gurrieri, L. (2012) 'The Don Draper Complex: Consuming work, Productive leisure and Marketer Boundary Work', Journal of Marketing Management, 28(7-8), pp. 784808.

Gutman, R. (1988) Architectural Practice: A Critical Review. New York: Princeton Architectural Press.

Gutman, R. (1997, 2010) 'Professions and their Discontents: The Psychodymanics of Architectural Practice'. In Cuff, D. \& Wriedt, J. (eds.) Architecture From the Outside In: Selected essays by Robert Gutman. New York: Princeton Architectural Press, pp. 43-60.

Hackley, C. and Kover, A. (2007) 'The Trouble with Creatives: Negotiating Creative identity in Advertising Agencies', International Journal of Advertising, 26(1), pp. 63-78.

Heynen, H. (2012) 'Genius, Gender and Architecture: The Star System as Exemplified in the Pritzker Prize', Architectural Theory Review, 17(2), pp. 331-45.

Hinings, C. R., Brown, J. L. and Greenwood, R. (1991) 'Change in an Autonomous Professional Organization', Journal of Management Studies, 28(4), pp. 375- 93.

Ibarra, H. (1999) 'Provisional Selves: Experimenting with Image and Identity in Professional Adaptation', Administrative Science Quaterly, 44, pp. 764-91.

Jarzabkowski, P., Lê, J. and Van de Ven, A. (2013) 'Responses to Competing Strategic Demands: How Organizing, Belonging, and Performing Paradoxes Coevolve', Strategic Organization, 0(0), pp. 1-36.

Joffe, M. and MacKenzie-Davey, K. (2012) 'The Problem of Identity in Hybrid Managers: Who are Medical Directors?', International Journal of Leadership in Public Services, 8(3), pp. 161-74.

Kornberger, M., Kreiner, K. and Clegg, S. (2011) 'The Value of Style In Architectural Practice', Culture and Organization, 17(2), pp. 139-53. 
Kreiner, G., Hollensbe, E. and Sheep, M. (2006) 'On the Edge of Identity: Boundary Dynamics at the Interface of Individual and Organizational Identities', Human Relations, 59(10), pp. 1315-41.

Kyratsis, Y., Atun, R., Phillips, N., Tracey, P. and George, G. (2016) 'Health Systems in Transition: Professional Identity Work in the Context of Shifting Institutional Logics', Academy of Management Journal, forthcoming.

Larson, M. S. (1977) The Rise of Professionalism: A Sociological Analysis. Berkeley: University of California Press.

Larson, M. S. (1993) Behind the Postmodern Facade: Architectural Change in Late Twentieth-Century America. Berkeley: University of California Press.

Lewis, M. (2000) 'Exploring Paradox: Toward a More Comprehensive Guide', Academy of Management Review, 25(4), pp. 760-76.

Locke, K., Golden-Biddle, K. and Feldman, M. S. (2008) 'Perspective-making Doubt Generative: Rethinking the Role of Doubt in the Research Process', Organization Science, 19(6), pp. 907-18.

Malhotra, M. and Morris, T. (2009) 'Heterogeneity in Professional Service Firms', Journal of Management Studies, 46(6), pp. 895-922.

Mallet, O. and Wapshott, R. (2012) 'Mediating Ambiguity: Narrative Identity and Knowledge Workers', Scandinavian Journal of Management, 28, pp. 16-26.

Mangen, C. and Brivot, M. (2015) 'The Challenge of Sustaining Organizational Hybridity: The Role of Power and Agency', Human Relations, 68(4), pp. 659-84.

McNeill, D. (2009) The Global Architect: Firms, Fame and Urban Form. London: Routledge.

Orton, J. (1997) 'From Inductive to Iterative Grounded Theory: Zipping the Gap Between Process Theory and Process Data.' Scandinavian Journal of Management, 13(4), pp. 419-38.

Paton, S. and Hodgson, D. (2016) 'Project Managers on the Edge: Liminality and Identity in the Management of Technical Work', New Technology, Work and Employment, 31(1), pp. 26-40.

Pelkonen, E. (2012) 'Architect as Organizer OR the Way the World Works', Perspecta, The Yale Architectural Journal, (Agency), pp. 7-15. 
Petriglieri, J. (2011) 'Under Threat: Responses to and the Consequences of Threats to Individuals' Identities', Academy of Management Review, 36(4), pp. 641-62.

Peirce, C. (1934) 'Collected Papers of Charles Sanders Peirce', in Hartshorne, C. \& Weiss, P. (eds.) Pragmatism and Pragmaticism. Cambridge, MA: Harvard University Press.

Pinnington, A. and Morris, T. (2002) 'Transforming the Architect: Ownership Form and Archetype Change', Organization Studies, 23(2), pp. 189-210.

Pratt, M., Rockmann, K. and Kaufmann, J. (2006) 'Constructing Professional Identity: The Role of Work and Identity Learning Cycles in the Customization of Identity Among Medical Residents', Academy of Management Journal, 49(2), pp. 235-62.

Rand, A. (1943) The Fountainhead. New York: The Bobbs-Merrill Company.

Ross, A. (2010) 'Foreword', in Deamer, P. \& Bernstein, P.G. (eds.) Building (in) the Future: Recasting labor in Architecture. New York: Princeton Architectural Press, pp. 9-16.

Sandberg, J. and Pinnington, A. (2009) 'Professional Competence as ways of Being: An Existential Ontological Perspective', Journal of Management Studies, 46(7), pp. 1138-70.

Siciliano, M. (2016) 'Disappearing into the Object: Aesthetic Subjectivities and Organizational Control in Routine Cultural Work', Organization Studies, 37(5), pp. 687-708.

Simpson, B. and Carroll, B. (2008) 'Re-viewing 'Role' in Processes of Identity Construction', Organization, 15(1), pp. 29-50.

Stern, R. (2010) 'Preface', in Deamer, P. \& Bernstein, P. (eds.) Building (in) the Future: Recasting Labor in Architecture. New York: Princeton Architectural Press.

Styhre, A. and Gluch, P. (2009) 'Creativity and its Discontents: Professional Ideology and Creativity in Architect Work', Creativity and Innovation Management, 18(3), pp. 224-33.

Suddaby, R., Gendron, Y. and Lam, H. (2009) 'The Organizational Context of Professionalism in Accounting', Accounting, Organizations and Society, 34, pp. 409-27.

Sveningsson, S. and Alvesson, M. (2003) 'Managing Managerial Identities: Discourse and Identity Struggle', Human Relations, 56(10), pp. 1163-93. 
Symes, M., Eley, J. and Seidel, A. D. (1995) Architects and Their Practices - A Changing Profession. UK: Butterworth Architecture.

Timmermans, S., \& Tavory, I. (2012). 'Theory Construction in Qualitative Research: From Grounded Theory to Abductive Analysis. Sociological Theory, 30(3), pp. 167-186.

Tombesi, P. (2010) 'On the Cultural Separation of Design Labor', in Deamer, P. \& Bernstein, P. (eds.) Building (in) the Future: Recasting labor in Architecture. New York: Princeton Architectural Press.

Thomas, G. (2011) 'A Typology for the Case Study in Social Science Following a Review of Definition, Discourse, and Structure', Qualitative Inquiry, 16(6), pp. 511-21.

Thomas, R. and Davies, A. (2005) 'Theorizing the Micro-politics of Resistance: New Public Management and Managerial Identities in the UK Public Services', Organization Studies, 26(5), pp. 683-706.

Vough, H. (2012) 'Not All Identifications Are Created Equal: Exploring Employee Accounts for Workgroup, Organizational, and Professional Identification', Organization Science, 23(3), pp. 778-800.

Wallenburg, I., Hopmans, C., Buljac-Samardzic, M., den Hoed, P. and Ijzermans, J. (2016) 'Repairing Reforms and Transforming Professional Practices: a Mixed-Methods Analysis of Surgical Training Reform', Journal of Professions and Organization, 3(1), pp. 86-102.

Wiscombe, T. (2006) 'Emergent Models of Architectural Practice: Architecture after All', Perspecta, The Yale Architectural Journal, 38, pp. 57-68. 
Table 1 Research participants

\begin{tabular}{lcl}
\hline Work undertaken & Number Interviewed & Respondents' role \\
\hline $\begin{array}{l}\text { Residential, } \\
\begin{array}{l}\text { Commercial, Transport, } \\
\text { Education, Health, }\end{array}\end{array}$ & 5 & Directors \\
$\begin{array}{l}\text { Sports, Master planning } \\
\text { and Public realm }\end{array}$ & 8 & Senior associates \\
& 9 & Project architects \\
& 10 & Associates \\
& 6 & Less than 5 years of experience \\
& 68 & Recent graduates \\
\hline
\end{tabular}


Figure 1

Data Structure

First-Order Codes

Statements about 'actual designing', 'everyone's got a reason to change it [design]', 'the bigger the project the more things can go wrong', 'we are control freaks', 'want to control the finer detail', 'I know it [design] can just drift'

Statements about 'huge numbers of people involved', 'who is actually making the decision', 'have to push really hard to get to the people making decisions', 'value engineering'

Statements about 'the project is the center of our universe', 'fortunate that we are a profitable

organization', 'you don't get to be director unless you bring in the work', 'commercial incentives to be profitable'

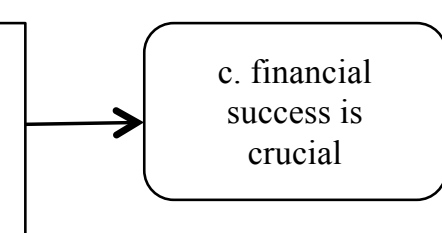

b. collaborative nature of design

a. ambiguity of authorship
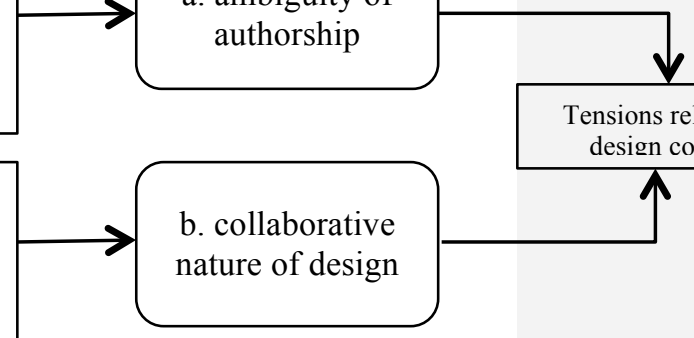

Tensions related to design control
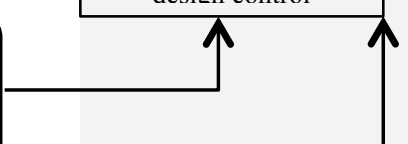

how changes to architects' practices lead to identity tensions

Tensions related to
Statements about 'we haven't abdicated the responsibility of projects and relationships', 'in the end...no matter how great the HR support is...there are more important ways of accessing talent'

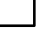

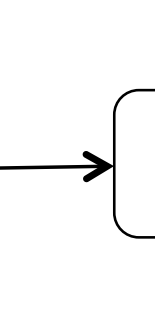

Statements about 'managing the day from meeting to meeting', 'I haven't done a drawing in over 10 years', 'things that have to be done [management tasks]', 'burdens'

\section{d. increased managerialism} professional autonomy
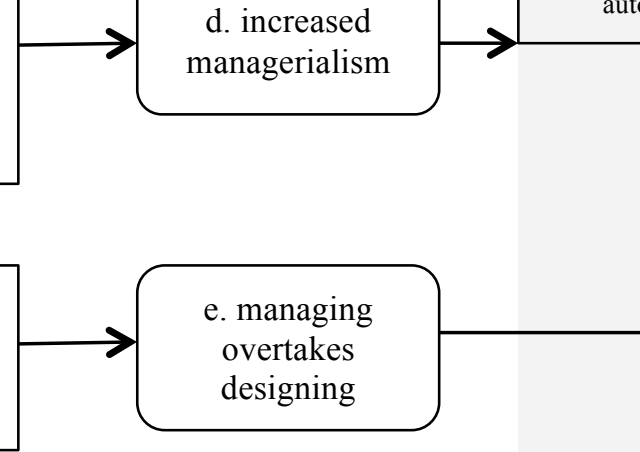

9

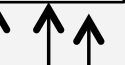

Statements about 'high level of engagement', 'being at the table when those decisions are made, 'every project needs a champion', 'stick their neck out', 'to plead for what is important [in the design]

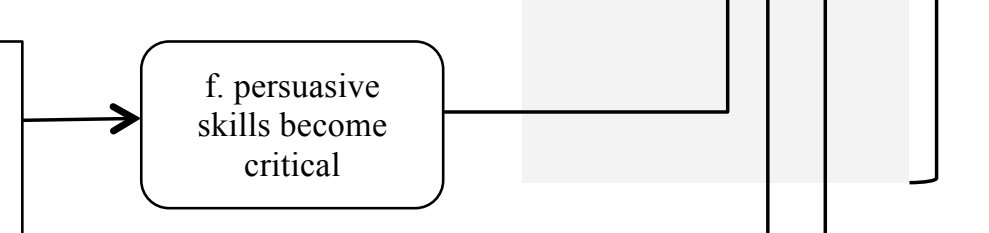

Statements about 'I am constantly amazed at how powerful the architect is', 'those things are frozen jammed cogs! until the architect draws something', 'well you know I'm saying it and they've just gotta DO IT!'

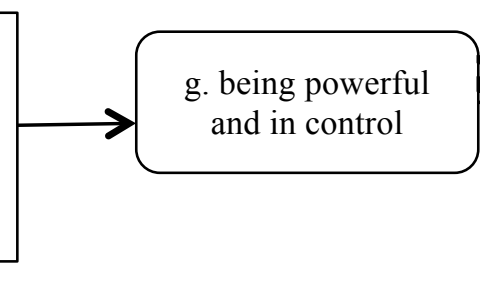

Statements about 'under threat', 'stand your ground', 'push back', we don't get enough credit for it [work], 'everyone thinks they are the most important person', 'many architects regard themselves as poets'

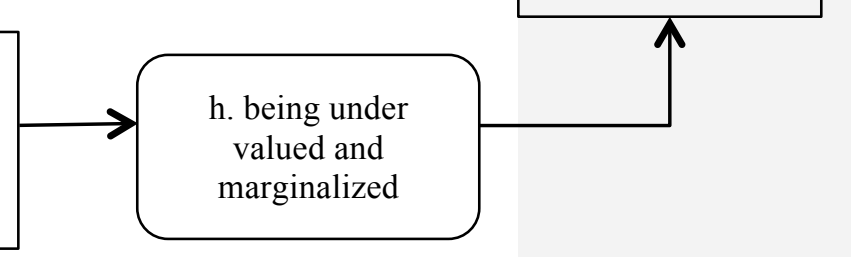

how identity tensions lead to paradoxical identity 